\title{
Perceived Effect of Climate Change on Forest Dependent Livelihoods in Oyo State, Nigeria
}

https://dx.doi.org/10.4314/jae.v22i2.15

\author{
Akinbile Luqman A. \\ Department of Agricultural Extension and Rural Development \\ University of Ibadan, Ibadan, Nigeria \\ Email: lakinbile@yahoo.com \\ Phone: +2348023250454 \\ Aminu Oluwafunmilayo 0 . \\ Department of Agricultural Extension and Rural Development \\ University of Ibadan, Ibadan, Nigeria \\ Email: funmiaminu83@gmail.com \\ Phone: +2348060990906
}

Kolade R. I.

Department of Agricultural Extension and Rural Development University of Ibadan, Ibadan, Nigeria

Email: kolade2018@yahoo.com

\begin{abstract}
The study investigated the perceived effect of climate change on forest dependent rural livelihoods in Oyo State, Nigeria with the view of identifying possible adaptation strategies. A total of 208 respondents were randomly sampled from Olokemeji and Onigambari forest reserves in Oluyole and Ibarapa East Local Government Area (LGA), respectively. Data collected were analyzed using frequency distribution, percentages Chi square and PPMC. Result shows that major livelihood activities were farming (100.0\%) and trading of forest products (92.8\%). Respondents were vulnerable to climate change effects with respect to undefined season (90.4\%), shortage of food production (84.1\%), reduction in crop yield (80.8\%), pest and disease outbreak (77.9\%) which affects their livelihood activities. Major adaptation strategies utilized were soil protection through tree planting (88.5\%), planting of different varieties of NTFPs and TFPs (87.0\%), practicing shifting cultivation (81.8\%) and use of organic fertilizer (81.7\%). Respondents' use of weather insurance was sparing in the study area. Significant relationship existed between farm size ( $r=-0.257$; $p \leq 0.01)$, monthly income $(r=-0.319$; $p \leq 0.01)$ and perceived effect of climate change. Adaptation strategies $(r=0.309 ; p \leq 0.05)$ used was significantly related with perceived effect of climate change. Afforestation should be encouraged among forest dependent farmers in addition to adaptation strategies utilised against climate change. The study recommends the need to educate farmers on the importance and benefit of weather insurance against financial loss due to climate change effects.
\end{abstract}

Keywords: Climate change, livelihood activities, forest products 
Creative commons User License: CC BY-NC-ND

Abstracted by: EBSCOhost, Electronic Journals Service (EJS), Google Scholar, Journal Seek, Scientific Commons,

Food and Agricultural Organization (FAO), CABI and Scopus
Journal of Agricultural Extension

Vol. 22 (2) June, 2018

ISSN(e): 24086851; ISSN(Print); 1119944X

http://journal.aesonnigeria.org

Email: editorinchief@aesonnigeria.org

\section{Introduction}

Climate change is used to describe a systemic change in the key dimensions of climate including average temperature, wind and rainfall patterns over a long period of time (IPCC, 2007). IPCC (2001) reported that Africa was predicted to suffer the most from impacts of climate change. According to Morgan et al. (2001), increase in temperature and level of atmospheric carbon dioxide as well as changes in precipitation have notable impact on the world's forests and the forest sector. However, climate change may increase and worsen the threats to forest, forest products and forest dependent people. Identification of cases of vulnerability of people living in and around forest reserves becomes necessary so as to suggest mitigations. Changing climate may increase and worsen the threats to forest and forest products, such as severe floods, drought, increased frequency of forest fires, landslides, increased temperature, rain variability, increase in carbon dioxide, rising sea levels, insects and disease outbreaks.

The importance of forest to man's survival cannot be overemphasized due to the various environmental, social and economic benefits it provides. Forest is a habitat for various species of trees, animals and fishes. More importantly, forest assists in the global cycling of water, oxygen, carbon and nitrogen; lend stability to hydrological system; regular supply of fresh water; prevents flood, soil erosion and situations of river bed downstream (Oregon Forest Resources Institute, 2018; Adebayo, 2009). According to United State Department of Agriculture (2011), forests play a critical role in maintaining the climate, freshwater systems, soils and biodiversity, all of which are critical to food security and other key aspects of human well-being. Forest helps in combating climate change through absorption and reduction of greenhouse gas such as carbon dioxide in the atmosphere. Various kinds of wood and nonwood items are derived from the forest. Forest supplies many products in form of wood which serves as basic material for construction, furniture, paper; and non-wood items which include extractions such as bark, dye, fibre, gum, incense, latexes, oil resins, waxes, shellac and tanning compounds, food, bush meats, flowers, fruits, honey/nuts, leaves, seeds, spices as well as decorative, ceremonial and medicinal items (Adebayo, 2009). Forest contributes to poverty reduction and agricultural stability by protecting the soil. The majority of the rural communities depend heavily on forest products for their livelihoods (MNRT, 2009).

Livelihoods are the sum of ways in which people make a living. Thus, income generation from forests is supplementing the farm income although not many households have the capacity to take advantage of forest-based income generating activities. Increasing agricultural production costs in relation to product prices and increasing living costs in general have pushed people to exploit forest more intensely, particularly on the general lands to generate cash income. Milledge et al. (2007) reported that forests support the livelihoods of $87 \%$ of the rural poor. However, the vulnerability of many communities in developing countries is immense and their capacity to adapt to future climate change impact is assumed to be very low (Huq and Reid, 2004).

United nation report says that unless government acts now to reduce greenhouse gas emissions (GHG) and adopt measures to protect their people, nobody will be 
immune to climate change. One impact is the reduction in yields, which leads to higher prices. The poor are always being hit harder in weather related disasters. Van-Aalst et al. (2007) asserted that it is the poor suffering more during the disaster and of course the same hazard causes a much bigger disaster in poorer countries. Climate change effect such as flood cause damage to crops, soil (erosion), houses, infrastructures, food shortages, spread of water borne diseases and disruption of settlements, commerce, transport and pressures on rural infrastructure. It also results in loss of human lives, livestock and uproot of trees. Increased temperatures increase fire risks in areas that experience increased aridity and climate change also promote the proliferation of diseases and pests that attack tree species. All these have a resultant effect on the livelihood of rural people that depend on forests for their subsistence and income. The challenges of climate risks on development and food security are enormous in Africa (Adger, 2006). Nigeria is one of the countries of the world which is potentially most vulnerable to climate change, because of its over dependence on forest.

It is therefore pertinent to investigate the current situation of individuals who depend on the forest for their means of livelihood. Hence, this study examined the perceived effect of climate change on forest dependent livelihoods by forest dwellers. This is a prerequisite for studying the effects and responses to future climate change and for identifying the key determinants of successful adaptation in the future (Adger et al., 2003).

\section{Methodology}

The study area is Oyo State, Nigeria. Oyo State is located in south western part of Nigeria and its capital is situated at Ibadan. The population of the study was all forests dependent households in Olokemeji and Onigambari forest reserve of Oyo state. In the two forest reserves, communities in and around the forest plantations within $2 \mathrm{~km}$ radius were identified. Three communities were randomly selected per reserve to give 6 communities sampled for this study. In Olokemeji forest reserve, Baale Olokemeji, Opete and Idi-ope were selected with respective estimated households of 404, 454 and 1015 while in Onigambari forest reserve, Onipe, Busogboro and Dalley villages were selected with respective households of 664, 1183 and 707. Respondents were sampled proportionately to the number of households in each community. Where the population was less than $500,10 \%$ was used; $5 \%$ was used for population between $500-1000$ while2.5\% was used for population over 1000. In Olokemeji forest reserve 40, 45 and 25 households were respectively sampled from Baale Olokemeji, Opete and Idi-ope while in Onigambari forest reserve 33, 30 and 35 householdswere sampled from Onipe, Busogboro and Dalley villages respectively. Hence, a total number of 208 household heads were used for this study. Interview schedule was used to elicit data from respondents. Data collected was analysed using descriptive statistics such as frequency, percentages and mean while inferential statistics such as PPMC was used to test hypotheses stated for the study. 
Creative commons User License: CC BY-NC-ND

Abstracted by: EBSCOhost, Electronic Journals Service (EJS), Google Scholar, Journal Seek, Scientific Commons,

Food and Agricultural Organization (FAO), CABI and Scopus
Journal of Agricultural Extension

Vol. 22 (2) June, 2018

ISSN(e): 24086851; ISSN(Print); 1119944X

http://journal.aesonnigeria.org

Email: editorinchief@aesonnigeria.org

\section{Result and Discussions}

\section{Socioeconomic Characteristics of Respondents}

The socioeconomic characteristics of respondents as presented in Table 1 show that majority $(63.3 \%)$ of the respondents were male, while $31.8 \%$ were female. This implies that there were more male headed households in the study area. The result is similar to the findings of Morakinyo et al (2015) who reported that most households in Nigeria were headed by male. The age category with the highest percentage of respondents was $41-50$ years $(32.7 \%)$. This implies that a greater proportion of the respondents were still in their active ages while others are tending towards old age. Most of the respondents were married (85.6\%) which suggests the importance attached to marriage institution and they should be apt to use climate change adaptation strategies in order to combat household vulnerability to climate change effects.

The majority (63.0\%) had primary education. This 'result implies that the majority of the respondents can read and write. Education will enhance respondents' access to information on climate change effects and adaptation strategies to be used. Thus, respondents' knowledge on the various ways to cushion the effects of climate change is enhanced. The results of this study align with Kong (2016) who found that most households sampled around Maasai Mau Forest, Narok County, Kenya were headed by male $(83.0 \%), 87.0 \%$ respondents were married, in their active years while $53.0 \%$ had primary education. Findings from this study show that Christianity is the dominant religion practiced by $68.3 \%$ respondents, $25.5 \%$ were Muslims, while only $6.2 \%$ were Traditionalists. Household size of most respondents is between 5-8 members and $93.3 \%$ had farm size less than 5 ha. The majority earned less than or equal to $\$ 20,000$ monthly were $45.7 \%$, while $32.2 \%$ earned between $\mathrm{N} 20,001$ A40,000 monthly. 
Table 1: Socio-economic characteristics of respondents

\begin{tabular}{llc}
\hline Variables & Categories & Percentages $(\mathbf{n = 2 0 8})$ \\
\hline Sex & Male & 68.3 \\
Age (years) & Female & 31.8 \\
& $\leq 30$ & 6.3 \\
& $31-40$ & 24.5 \\
& $41-50$ & 32.7 \\
Marital status & $51-60$ & 22.6 \\
& $>60$ & 13.9 \\
& Single & 3.8 \\
& Married & 85.6 \\
Education & Widowed & 6.3 \\
& Divorced & 4.2 \\
& No formal education & 12.5 \\
Religion & Primary & 63.0 \\
& Secondary & 24.0 \\
Household size & Tertiary & 0.5 \\
& Christianity & 68.3 \\
& Islam & 25.5 \\
& Traditional & 6.2 \\
& $<5$ & 12.0 \\
Farm size (ha) & $5-8$ & 64.9 \\
& $9-12$ & 16.8 \\
Monthly income $(\AA)$ & $13-16$ & 6.3 \\
& $<5$ & 93.3 \\
& $5-7$ & 4.8 \\
& $8-10$ & 1.9 \\
& $20,001-40,000$ & 45.7 \\
& $40,001-60,000$ & 32.2 \\
& $60,001-80,000$ & 13.9 \\
& $>80,000$ & 6.3 \\
& & 1.9 \\
\hline
\end{tabular}

Field Survey 2016

\section{Income Generating Livelihood Activities}

Table 2 reveals that all respondents engaged in farming activities. Since all respondents engaged in farming, their vulnerability to climate change effects will be more. According to FAO (2005), farming, forestry and fishery are highly sensitive to climate change which will have a serious impact on farmers' production functions. It was found that the majority engaged in gathering of NTFPs (96.2\%) and trading of forest products (92.8\%). This aligns with Onyekuru and Marchant (2014) who found that forest resources contribute to the livelihoods of households across Nigeria. Similarly, Dube and Phiri (2013) found that food security among African communities in Zimbabwe has always been supported by NTFPs. Corroborating this, Falconer (1994) findings reveal that NTFPs play an important role in the Ghanaian economy by the way of supporting rural livelihoods. Other livelihood activities engaged in by respondents are livestock rearing (31.3\%), hired labour (40.9), Hunting (38.5\%) and Artisan (29.8\%). In Kenya, Langat et al (2016) reported that rearing of livestock contributed to livelihoods of communities living close to the forest. 
Table 2: Income generating livelihood activities

\begin{tabular}{lc}
\hline Income generating livelihood activities & Percentages $\mathbf{( n = 2 0 8 )}$ \\
\hline Farming & 100.0 \\
Livestock rearing & 31.3 \\
Trading of forest products & 92.8 \\
Fishing & 5.3 \\
Hired labourer & 40.9 \\
Hunting & 38.5 \\
Artisan & 29.8 \\
Gathering of NTFPs & 96.2 \\
Transport business & 4.3 \\
Civil servants & 1.9 \\
\hline
\end{tabular}

Field Survey 2016

\section{Vulnerability of Respondents to Climate Change Effects}

Table 3 reveals that most respondents were seriously and partially vulnerable to climate change effects with respect to undefined season (90.4\%), shortage of food production $(84.1 \%)$, reduction in crop yield $(80.8 \%)$, pest and disease outbreak $(77.9 \%)$ which affects income derived from livelihood activities. Onyekuru and Marchant (2014) stated that in Nigeria, people are highly vulnerable to climate impacts because it acts on the very essence of their sources of livelihoods, upon which they depend on daily basis for sustenance. Hence, increased uncertainties in climate variability is a major challenge for sustaining agriculture as well as allied sectors in the face of already declining forest resources.

Table 3: Vulnerability to climate change effects

\begin{tabular}{lccc}
\hline Items & Not at all & Partial & Serious \\
\hline Reduction in yield & 19.2 & 38.0 & 42.8 \\
Flooding & 54.8 & 30.8 & 14.4 \\
Shortage of food & 15.9 & 47.1 & 37.0 \\
Undefined seasons & 9.6 & 50.5 & 39.9 \\
Pests and diseases outbreak & 22.1 & 49.5 & 28.4 \\
\hline
\end{tabular}

\section{Field Survey 2016}

\section{Perception of Climate Change Effects}

Table 4 shows that most of the respondents agree that rainfall fluctuation is never in favour of forest products $(\bar{x} \bar{X}=3.96)$ and that cultivation of forest products will decrease the problem of land degradation ( $\bar{x} \bar{X}=3.96$ ). Majority of the respondents attest that unpredictable nature of sun intensity negatively affects forest products $(\bar{x}=3.88)$. Increase in temperature was perceived as a threat to forest products by respondents $\bar{x}=3.84)$. Other effects of climate change experienced in the area include decreased yield $(\bar{x}=3.56)$, high humidity $(\bar{x}=3.24)$, disease infection $(\bar{x}=3.16)$ and pest infestation ( $\bar{x}=2.93)$. Findings from this study aligns with Ugwuoke (2013) who reported that farmers in Abia State, Nigeria experienced climate change effects such as poor relative humidity, decrease in agricultural yield, high sunshine intensity, 
increase in temperature, change in pattern of rainfall and poor fertility of most soils. High intensity of sun and unpredictable changes in rainfall pattern were also reported among farmers in Ondo State, Nigeria (Thompson and Oparinde, 2015). The result of this study also establishes adverse effects of climate change in rural areas as reported by IPCC (2007).

Table 4: Respondents' perception of climate change effect

\begin{tabular}{|c|c|c|}
\hline Perception statements & Mean & Rank \\
\hline $\begin{array}{l}\text { The rise in annual rainfall had not led to increase yield of } \\
\text { forest products }\end{array}$ & 3.56 & $4^{\text {th }}$ \\
\hline Fluctuation of rainfall is never in favour of forest products & 3.96 & $1^{\text {st }}$ \\
\hline $\begin{array}{l}\text { Forest products are lost to disease infection on the field } \\
\text { due to high relative humidity }\end{array}$ & 3.16 & $6^{\text {th }}$ \\
\hline $\begin{array}{l}\text { There is high incidence of pest due to change in } \\
\text { temperature and rainfall pattern }\end{array}$ & 2.93 & $7^{\text {th }}$ \\
\hline $\begin{array}{l}\text { Cultivation of forest products will decrease the problem of } \\
\text { land degradation }\end{array}$ & 3.96 & $1^{\text {st }}$ \\
\hline High humidity does not increase yield of forest products & 3.24 & $5^{\text {th }}$ \\
\hline Increase in temperature threatens forest products & 3.84 & $3^{\text {rd }}$ \\
\hline $\begin{array}{l}\text { Unpredictable nature of sun intensity negatively affects } \\
\text { forest products }\end{array}$ & 3.88 & $2^{\text {nd }}$ \\
\hline
\end{tabular}

\section{Adaptation Strategies to Climate Change Effects Utilized}

Table 5 reveals that $88.5 \%$ employ soil protection through tree planting. This agrees with the findings of Ofuoku (2011) that rural farmers in Delta State, Nigeria employ planting of trees as an adaptation measure against climate change. It was discovered that most respondents $(87.0 \%)$ indicate they employ planting of different varieties of NTFPs and TFPs as an adaptation strategy to climate change. This is consistent with Onyekuru and Marchant (2014) findings that among the adaptation strategy option identified, planting of NTFPs and TFPs stood out as the choice of most farmers. Furthermore, result shows that most respondents practice shifting cultivation (81.8\%), use organic fertilizer (81.7\%) and irrigation $(63.0 \%)$ in the study area. This is supported by the report of Okpe and Aye (2015) and Osasogie and Omorogbe (2018) that farmers in Benue State, Nigeria employ the use of chemical fertilizer and irrigation as an adaptation strategy to climate change effects. The use of different planting dates was employed by $62.0 \%$ of the respondents. Likewise, in Ekiti State, Nigeria, changing of planting and harvest time was reported as the most widely adaptation strategy used by the farmers (Ajayi, 2016). Soil conservation is another important adaptation strategy used by $58.7 \%$ of the respondents. Soil nutrients can by conserved by the use of methods such as mulching, crop rotation and planting of cover crops. Studies have shown the use of mulching, crop rotation and planting of cover crops as adaptation strategies among farmers in Nigeria (Ajayi, 2016; Okoroh, et al., 2016 and Arimi, 2014). 
Table 5: Adaptation strategies to climate change effects utilized

\begin{tabular}{lc} 
Adaptation strategies & Percentages \\
\hline Planting of different varieties of NTFPs and TFPs & 87.0 \\
Different planting dates & 62.0 \\
Practicing shifting cultivation & 81.8 \\
Increase irrigation & 63.0 \\
Use of organic fertilizer & 81.7 \\
Increase water conservation & 26.9 \\
Soil conservation & 58.7 \\
Use of weather insurance & 34.6 \\
Soil protection through tree planting & 88.5 \\
Desalination & 38.9 \\
\hline
\end{tabular}

Field Survey 2016

\section{Relationship Between Selected Independent Variables and Perceived Effect of Climate Change}

Table 8 reveals that a negative significant relationship exists between farm size ( $r=-$ $0.257 ; p \leq 0.01)$, monthly income $(r=-0.319 ; p \leq 0.01)$ and perceived effect of climate change. This implies that effect of climate change is more felt by respondents with small holdings who might lack adaptive capacity coupled with limited income compare with respondents with large farm holdings. The inverse relationship between monthly income and perceived effect of climate change suggests that respondents with limited income from livelihood activities are those who perceived climate change effects to be most serious. The relationship between adaptation strategies and perceived effect of climate change $(r=0.309 ; p \leq 0.05)$ was positively significant indicating that those who perceived climate change effects to be high utilized adaptation strategies the most.

Table 8: PPMC analysis of selected independent variables with perceived effect of climate change

\begin{tabular}{ll}
\hline Variables & r value \\
\hline Farm size & $-0.257^{\star}$ \\
Monthly income & $-0.319^{\star}$ \\
Adaptation strategies & $0.309^{*}$
\end{tabular}

\section{${ }^{*} \mathrm{P} \leq 0.05$. Field Survey 2016}

\section{Conclusion and Recommendations}

The study concludes that households are mostly headed by men who are adults, married, formally educated and are engage in farming as their primary means of livelihood. Respondents were involved in gathering of non-timber forest products and its sales. Vulnerability of respondents to climate change effects such as undefined season, shortage of food production, reduction in crop yield, pest and disease outbreak was considered serious. The major effects of climate change perceived to 
be high were irregular rainfall and unpredictable sun intensity. Adaptation strategies used by most respondents were soil protection through tree planting, planting of different varieties of NTFPs and TFPs and practicing of shifting cultivation. However, respondents' use of weather insurance was sparing in the study area. The study recommends the need to educate farmers on the importance and benefit of weather insurance against financial loss due to climate change effects.

\section{References}

Adebayo, A. A. (2009). Attaining sustainable rural development in Nigeria through effective management of forest based resources. International Journal of Creativity and Technical Development Vol. 1(3): 32-45. Retrieved from https://www.icidr.org/doc/ICIDR\%20PDF\%20contents/journal\%20of\%20research\%20 in\%20education\%20and\%20society/IJCTD_v1no1to3/attaining\%20sustainable\%20ru ral.pdf

Adger W. N. (2006). Vulnerability. Global Environmental Change Vol. 16 (3):268-281. https://doi.org/10.1016/j.gloenvcha.2006.02.006

Adger W. N., Brown K., Conway D. and Hulme M. (2003). Adaptation to climate change in the developing world. Programme Development Studies (3):179-195.

Ajayi J. (2016). Adaptation Strategies to Climate Change by Farmers in Ekiti State, Nigeria. Applied Tropical Agriculture. 20. 1-7. Retrieved from https://www.researchgate.net/publication/299930015_Adaptation_Strategies_to_Clim ate_Change_by_Farmers_in_Ekiti_State_Nigeria

Arimi K. (2014). Determinants of climate change adaptation strategies used by rice farmers in Southwestern, Nigeria. Journal of Agriculture and Rural Development in the Tropics and Subtropics Vol. 115(2): 91-99 www.jarts.info

Ayers, J and Huq, S. (2009). The value of linking mitigation and adaptation: A case study of Bangladesh. Environmental Management 43(5). Basu, J. P. (2009). Adaptation, NonTimber Forest Products and Rural Livelihood: An Empirical Study in West Bengal, India. Earth and Environmental Sciences pp3-8

Blessing E. Okpe1 and Goodness C. Aye1 (2015). Adaptation to Climate Change by Farmers in Makurdi, Nigeria. Journal of Agriculture and Ecology Research International Vol. 2(1): 46-57, Retrieved from, http://www.journalrepository.org/media/journals/JAERI_37/2014/Oct/Okpe212014JA ERI12169_1.pdfw

Dube, T. and Phiri, K., (2013). Rural Livelihoods under Stress: The Impact of Climate Change on Livelihoods in South Western Zimbabwe. American International Journal of Contemporary Research Vol. 3(5).

Falconer, J. (1994).Non-timber forest products in southern Ghana: main report. Republic of Ghana Forestry Department, Ghana, and Overseas Development Administration, Natural Resources Institute, Chatham, UK.Series No. 2. Pp 1-235 
Creative commons User License: CC BY-NC-ND

Abstracted by: EBSCOhost, Electronic Journals Service (EJS), Google Scholar, Journal Seek, Scientific Commons,

Food and Agricultural Organization (FAO), CABI and Scopus
Journal of Agricultural Extension

Vol. 22 (2) June, 2018

ISSN(e): 24086851; ISSN(Print); 1119944X

http://journal.aesonnigeria.org

Email: editorinchief@aesonnigeria.org

Food and Agricultralorganization (FAO) (2005). Adaptation of forest ecosystems and the forest sector to climate change. Forests and Climate Change Working Paper No. 2, Rome, FAO/Swiss Agency for Development and Cooperation.

Huq S. and Reid H. (2004). Mainstreaming adaptation in development IDS Bulletin 35(3):1521. DOI. 10.1111/j.1759-5436.2004.tb00129.x.

Intergovernmental Panel on Climate change (IPCC) (2001). Climate Change 2001 Synthesis Report. A contribution of working groups I, II and III to the third assessment report on the Intergovernmental Panel on Climate Change. Watson, R. T. and the Core Writing Team (Eds.). Canbridge University Press, Cambridge, p. 398

Intergovernmental Panel on Climate change (IPCC) (2007). Climate Change 2007: Impacts, Adaptation and Vulnerability. In: Parry M. L, Canziani O. F., Palutikof J. P., van der Linden P. J. and Hanson C. E . (Eds.) Contribution of working groups II to the fourth assessment report on the Intergovernmental Panel on Climate Change. Cambridge University Press, Cambridge, UK. p. 973.

Kong L. N. S. (2016). Relationship between community livelihood options and climate change knowledge and practices: a case study of Maasai Mau forest, Narok County, Kenya. A Thesis submitted to the University of Nairobi in partial fulfillment of the requirements for the award of Master of Science Degree in Environmental Governance.

Langat D. K., Maranga E. K., Abond A. A. and Cheboiwo J. K. (2016). Role of Forest Resources to Local Livelihoods: The Case of East Mau Forest Ecosystem, Kenya. International Journal of Forestry Research, Vol. (2016)1-10 http://dx.doi.org/10.1155/2016/4537354

Milledge S. H., Gelvas I. K. and Ahrends A. (2007). Forestry, Governance and National Development: Lessons learned from a logging boom in Southern Tanzania. An overview, TRAFFIC East/Southern Africa/Tanzania Development Partners Group/Ministry of Natural Resources of Tourism, Dar es Salaam, Tanzania. 256pp

Mircea Sandru (2012). Ways Forests Benefit the Environment. Retrieved from https://www.greenoptimistic.com/7-ways-forests-benefit-the-environment20121017/\#.WyeBf1 VKjlU

Ministry of Natural resource and Tourism (MNRT) (2009). Participatory forest management in Tazania: 1993-2009, lessons learned and experiences to date. Forestry and Bee Keeping Division. 72pp

Morakinyo O. M, Adebowale S. A and Oloruntoba E. O (2015). Wealth status and sex differential of household head: implication for source of drinking water in Nigeria. Journal of the Belgian Public Health Association (2015)73:58, https://doi.org/10.1186/s13690-015-0105-9

Morgan M. G., Pitelka L. F. and Shevliakova E (2001). Elicitation of export judgements of climate change impacts on forests ecosystems. Climate Change 49:279-307

Msalilwa, U., Augustino, S. and Gillah, P.R. (2013). Community perception on climate change and usage patterns of non-timber forest products by communities around Kilolo District, Tanzania. Ethiopian Journal of Environmental Studies and Management Vol. (6)5:507-517 http://dx.doi.org/10.4314/ejesm.v6i5.8 
Creative commons User License: CC BY-NC-ND

Abstracted by: EBSCOhost, Electronic Journals Service (EJS),

Google Scholar, Journal Seek, Scientific Commons,

Food and Agricultural Organization (FAO), CABI and Scopus
Journal of Agricultural Extension

Vol. 22 (2) June, 2018

ISSN(e): 24086851; ISSN(Print); 1119944X

http://journal.aesonnigeria.org

Email: editorinchief@aesonnigeria.org

Ofuoku A. U. (2011). Rural farmres'perception of climate change in Central Agricultural Zone of Delta State, Nigeria. Indonesia Journal of Agriculture 12(2): 63-69.

Okoroh J. P., Olaolu M. O. and Igbokwe E. M. (2016). Climate Change Mitigation and Adaptation Strategies Used by Farmers in Imo State, Nigeria. Journal of Agricultural Extension, Vol. 20(6): 130-142. http://dx.doi.org/10.4314/jae.v20i2.10

Okpe B. E. and Aye G. C. (2015). Adaptation to Climate Change by Farmers in Makurdi, Nigeria. Journal of Agriculture and Ecology Research International Vol. 2(1): 46-57, Retrieved from, http://www.journalrepository.org/media/journals/JAERI_37/2014/Oct/Okpe212014JA ERI12169_1.pdfw

Onyekuru A. N. and Marchant R. (2014). Climate Change Impact and Adaptation Pathways for Forest Dependent Livelihood Systems in Nigeria. African Journal of Agricultural Research Vol. 9(24):1819-1832 retrieved from http://www.academicjournals.org/article/article1402999015_Onyekuru\%20and\%20M archant.pdf

Oregon Forest Research Institute (2018). The many benefits of forest. Retrieved from https://www.oregonforests.org/Forest_Benefits

Osasogie D. I. and Omorogbe I. (2018). Socioeconomic Determinants of Farmers Adaptation Strategies to Climate Change Hazards in Benue state, Nigeria. Journal of Biodiversity, Bioprospecting and Development, Vol. 5(1):1-6 DOI: 10.4172/23760214.1000169

Sharma N. (1992). World Forests in Perspertives. In Sharma N. P. and Dubuque I. A. (Eds) Managing the World's Forests Looking for Balance between Conservation and Development. Kendall/Hunt Publishing Company.

Thompson, O. A. and Oparinde, L. O (2015). Farmers' perception of climate change in Ondo State, Nigeria. Nigerian Journal of Agricultural Economics, Vol. 6(1): 22-30. Retrieved from

http://ageconsearch.umn.edu/record/267991/files/Volume\%206\%20\%281\%29R_Tho mpson.pdf

United State Department of Agriculture - USDA (2011). The Role of Forests in Sustainable Development. Retrieved from https://www.fs.fed.us/speeches/role-forestssustainable-development

Ugwuoke, A. F. (2013). Farmers' Perception of Climate Change in Ikwuano Local Government Area of Abia State, Nigeria. Journal of Biology, Agriculture and Healthcare Vol.3(6): 36-45, www.iiste.org

Van Aalst M, Hirsch D and Tellam I (2007). Poverty Reduction at Risk - Managing the Impacts of Climate Change on Poverty Alleviation Activities. ETC, Leusden, The Netherlands. http://www.nlcap.net/uploads/media/Poverty_Reduction_at 